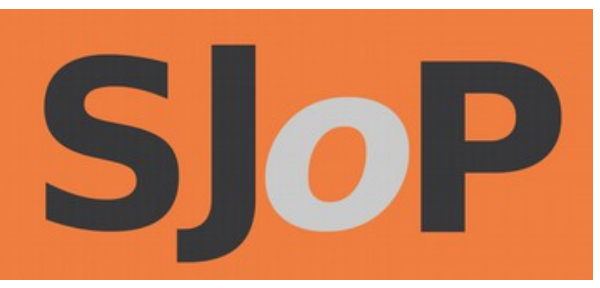

\title{
Practitioner report: Running walls: the performance of the limit in prison
}

\section{PAOLO MACCAGNO}

The Scottish Journal of Performance

Volume 2, Issue 2; June 2015

ISSN: 2054-1953 (Print) / ISSN: 2054-1961 (Online)

Publication details: http://www.scottishjournalofperformance.org

To cite this article: Maccagno, P., 2015. Practitioner report: Running walls: the performance of the limit in prison. Scottish Journal of

Performance, 2(2): pp.33-59.

To link to this article: http://dx.doi.org/10.14439/sjop.2015.0202.03

(CC) $\begin{aligned} & \text { This work is licensed under a Creative Commons } \\ & \text { Attribution } 4.0 \text { International License. See } \\ & \text { http://creativecommons.org/licenses/by/4.0/ for details. }\end{aligned}$ 
PRACTITIONER REPORT:

\section{Running walls: the performance of the limit in prison}

PAOLO MACCAGNO

DOI: 10.14439/sjop.2015.0202.03

Publication date: 26 June 2015

Humanity does not start out from freedom but from limitation (Foucault, 1995, p.292).

The limit to freedom, represented by the wall of the prison, is the limit to run to reach the finish-line of the marathon: run the limit! Training prisoners to run a marathon as a practice of the limit. Inside and outside meet on the limit, in a suspended place where running is a movement of rehabilitation and transformation.

Go Daddy! is an educational project based upon the pedagogy of resilience and a form of anthropological research into body and movement. It is a case study investigating personal limits through an art performance based on marathon running with prisoner-fathers; a limitexperience as a 'practice of freedom' (Foucault) to activate the prison and through it see a social system where neoliberalism is expressed; a pilot project for wider research at the intersection of different academic traditions, pointing towards a new direction for critical engagement with performance. Drawing from that experience, this article examines the potentialities of marathon running in prison as a performance of limits: a healing possibility for personhood to be based on 'presence' (Abramović) and 
awareness, since, as Foucault notes, the experiential body can become a locus of resistance against normalising power. Through analysis of the Go Daddy! project, this paper considers how an art performance can be an experiment in the sense not of testing a hypothesis but of opening an exploratory path of inquiry into human life and a new way of conducting anthropology as a learning process -in other words, the possibility for art to be science.

Keywords: marathon, running, prison, walls, presence, limit

\section{Introduction}

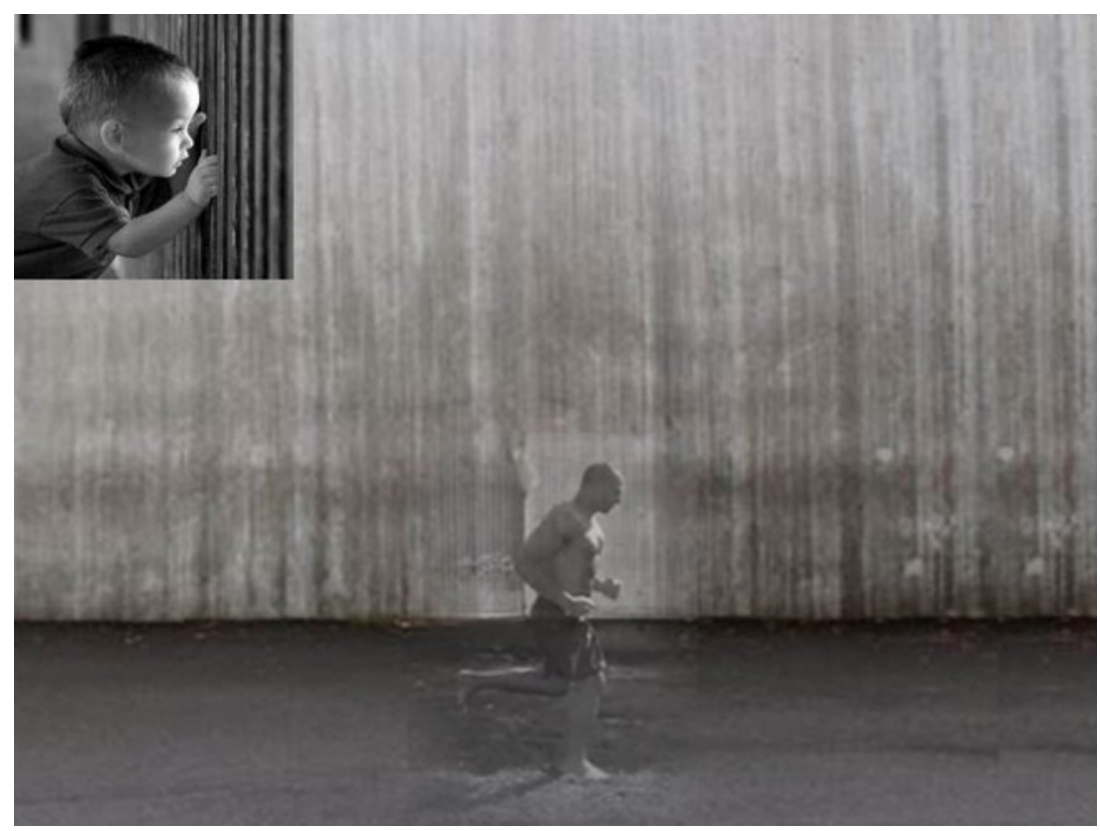

Loïc Wacquant makes the claim that social scientists must get 'in and out of the belly of the beast' in order to overcome 'the curious eclipse of prison ethnography in the age of mass incarceration' (2002, p.371). In response to this claim, the Go Daddy! project provides a new concept for academic inquiry pointing towards a new direction for critical engagement with performance. It proposes marathon running in prison as an action for prisoners and 
researchers to perform. Conceived as a practice of the limit that plays with boundaries, it takes the form of an art performance, and at the same time an inquiry into the possibilities of leading a group of people through creative processes where body and movement are at the core of the experience and a source of knowledge, opening the possibility of science in the 'first person' (Varela, 1996; 1999).

In combining prison research with performance studies and touching on themes of neoliberalism, liminal identities and the body, this paper provides an interdisciplinary contribution to social science concentrating on discipline and resistance through the notion of the limit, from the perspective provided by the theoretical frame of Foucault's concept of the limit-experience (1994).

This research highlights the ambiguous connection between different forms of 'discipline', of societal norms of rehabilitation and family, and how these forms are challenged by the performance of marathon running. Go Daddy! proposes the paradox of contrasting imprisonment with marathon running and the exploration of its potentialities in juxtaposing two very different experiences that both test the human being's capacity. Drawing in particular on the anthropology and phenomenology of the body, this study shows how this contrast provides a space for resisting the limits imposed by prison, suggesting possibilities of dignity and personhood. The paper first introduces the research project Go Daddy! in terms of methodology, positionality and process. It then explores the notion of limit in the experience of the wall of the marathon runner and in the walls of the prison, challenging the traditional understanding of the concept as a space of transition between different states of being (van Gennep, 2010; Turner, 1969). In conclusion, it shows how the notion of limit emerging from the research, as explored in different contemporary fields of knowledge ranging from 
anthropology, cultural geography and art, can overcome the idea of a linear progression between states and focus on the condition of liminality itself as a permanent dimension of life where presence offers a possibility of freedom.

\section{Go Daddy! Marathon running in prison: context and method}

Since the beginning of 2013, I have been working inside Bollate prison (Milan). Thanks to the cooperation of Bambinisenzasbarre $^{1}$, an NGO working in direct contact with the Italian Government for the rights of parentprisoners to exercise their parenthood, I developed a project where I worked with prisoners through marathon running. Go Daddy! is an educational project situated in the pedagogy of resilience involving a group of 20 fathers serving in Bollate prison. Starting at the beginning of 2013, it finished its first phase in June 2014 after the 'team of lost fathers' participated in the Milan city marathon.

Bollate prison is situated to the North-West of Milan. It accommodates slightly more than 1,000 prisoners-men and women-who are serving at least five years. It has a utopian vision of inmate relationality at the heart of prisoner corrections. It does so by encouraging prisoners to become (better) citizens, for example through being tolerant of and affectionate towards others. Prisoners are subject to a strict monitoring regime where their capacity to engage in good relations is scrutinised. The prison offers 'rooms of affection', which provide prisoners and their families the opportunity to spend meaningful quality time together. In so doing, family bonds are strengthened thanks to a friendly visiting environment which fosters desistance from crime.

Following this model of intervention promoted by the new penal authority (2009), Bambinisenzasbarre developed a 
project called 'The Yellow Space', a room inside the prison where children meet with their parent-prisoner. Go Daddy! is an idea that expands The Yellow Space beyond the walls of a room into a space to run between the inside and outside.

Supporting Bambinisenzasbarre's core objective, one of the main goals of the project was to foster and promote fatherhood. Go Daddy! was designed as a pilot project to test the potentialities of such an innovative approach. Many decisions were therefore taken to simplify the first experiment. Only 20 fathers were accepted (men only, because women are placed in another building and cannot mix). These men were already part of other Bambinisenzasbarre group discussions and projects, and were therefore familiar with organisation's ethos. The prisoners were each serving different lengths of sentence, but were generally in the last years of their imprisonment. For this project, I was a volunteer offering marathon running training. Every week, for the entire duration of the project, we had a three-hour appointment on Thursday morning, divided into a running technique class (using images and videos), and a training session running close to the walls of the prison. The course fitted into the prison regime without disturbing its equilibrium: the choice of day and time took into account the need for prisoners to participate without conflicting with the many tasks required by the prison (for example, work and educational courses). Running close to the prison walls was an important step forward after a few months spent running in circles around small football fields, which, according to the prison's rules, was the only space for prisoners who wanted to run. At the beginning of the project, we accepted this condition, but created better possibilities during the process. The course provided every prisoner-runner with his own programme, including: team/group coaching every week (class, Feldenkrais ${ }^{2}$ lesson, running); an individual timetable to carry out alone during the week; a running log; practice races; and finally the marathon itself. 
Based on this experience, I developed a research project focusing on running, physical exertion, and bodily discipline to understand what this process had to say about prison and the kinds of subjectivity it generates. The limitexperience of the marathon has been used as a methodological tool to put the prison to work and to activate it as a system. Through different bodywork techniques (running, Feldenkrais method), body-biographies, field notes and informal discussions, my intention was to explore the following research questions:

- How does the experience of freedom and presence that is connected to a marathon relate to the process of subjectification imposed by the prison?

- How can this practice operate to improve the quality of relationships between fathers and children?

\section{The wall of the marathon runner}

\section{Limit-experience as a practice of freedom}

The idea of a limit-experience functions to uproot the individual from himself, [to position him] where he is no longer himself, and where he will be carried to his own annihilation or dissolution. This is an activity/work of de-subjectification (Foucault, 1994, p.43). 


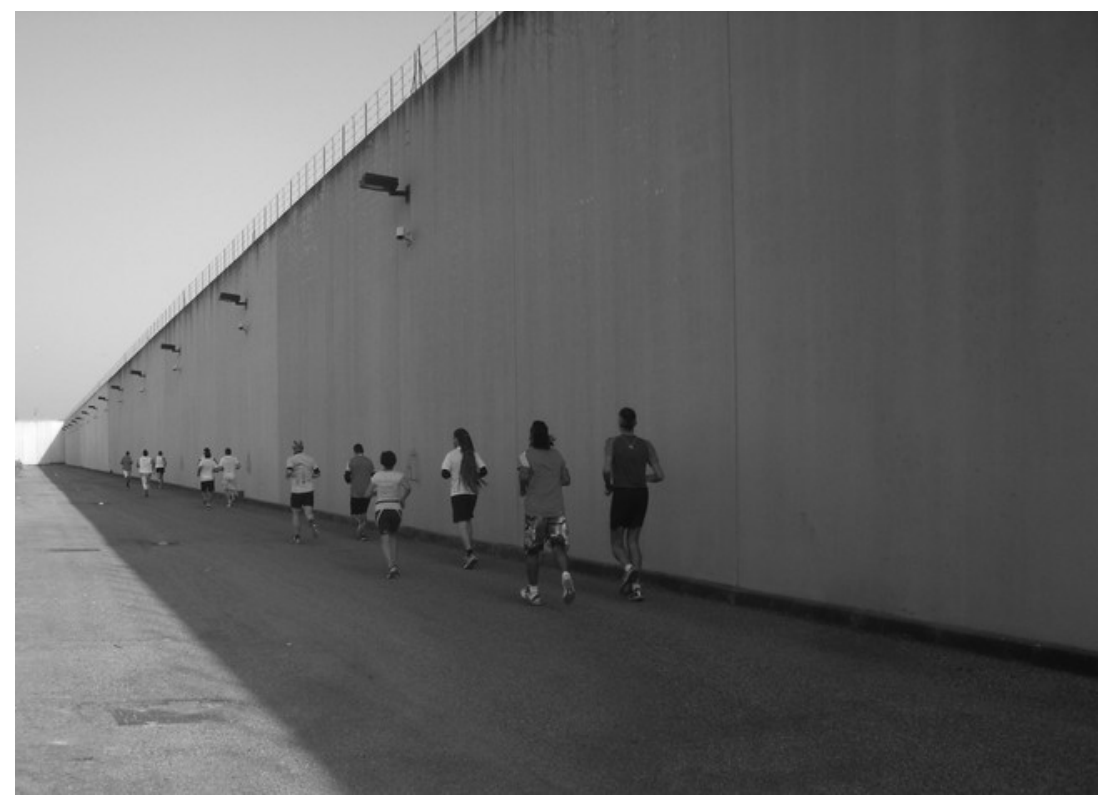

As Foucault described, the limit-experience is an active 'pratique de libertè' (practice of freedom) where freedom is tightly connected to ethics, as care of the Self (Holmes et al., 2006). The limit experience is not research of the extreme or a codified rite of passage ${ }^{3}$ but an existential opening belonging to diffused anonymous and anarchic practices, producing frail individuals challenging the established order. It is close to the idea of 'edgework' on which several sociologists and anthropologists (Jay, 1995; Lyng, 2004; Oksala, 2004; Tobias, 2005; Holmes et al., 2006) are working to explore the meaning of high-risk practices. This range of activities shares the common attraction of exploring the limits of human experience in the complex process of selfcreation to discover new possibilities of embodied existence (Lyng, 2004) within a panoptic and disciplinary society.

The first thing I told the group of prisoners on our initial meeting was that we were not just going to run, but were going to run a marathon! The idea was to face the limit, a peculiar experience in the marathon popularly referred to in Italian as the 'wall of the marathon runner', or in English as 'hitting the wall' (Stevinson and Biddle, 1998). 
Participating in a marathon implies accepting a subjectification given by the race itself in terms of classification and personal branding. It is an exercise in identity construction and voluntary submission. But at the same time, in a marathon every runner has to face a noman's-land at around the $20^{\text {th }}$ mile, the so-called 'wall of the marathon runner', in order to cross the finish-line. The strain produced whilst experiencing 'the wall' can destroy any sense of identity, and with it cultural background, forcing the runner to direct their gaze towards emptiness. To overcome the wall $\mathrm{s} /$ he has to think of it not as a separating line but as a limit, an unknown space, a 'wilderness', a threshold to explore. At the limit, the marathon runner stops feeling imprisoned and confined within an 'identity' and discovers their own 'presence' (de Martino, 1997) in the free act of running. The marathon, therefore, is a 'limit-experience' (Foucault, 1994, p.43) of transformation that 'undermines the subject' (Jay, 1995, p.158). The limit offers the possibility of change and transformation, and the marathon is a practice of freedom.

I am learning not to win... and it is beautiful! (prisoner's words, translated from Italian by author throughout)

Running the 'wall of the marathon runner' highlighted different signs of resistance between prisoners. The above words show a process of learning where prisoners started to accept new possibilities of meaning-even if these were in contrast to the stereotypes and social values as normally recognised. When a new prisoner joined the group, those who had been in the programme for longer immediately informed him about the difference between running and running a marathon: 'maybe you are a fast runner, but here we run differently... what counts is resistance in the long run'. Each prisoner had to find the strength to resist the 
'obligation to win' during a race, leaning on the feeling of pleasure and beauty that comes from the practice. Indeed, even if the finish line and chronometer are strong motivations for every runner in the marathon, if you want to arrive at the end in the best way, you mustn't think about the finish line: you have to run as if you would run forever! The experience of strain requires a particular attitude (Maccagno, 2015).

\section{Running in prison}

'Let's run together!', I proposed to the group of prisoners. Running is a movement, therefore a way of perception ${ }^{4}$ (Merleau-Ponty, 1962); it is 'thinking in movement' (SheetsJohnstone, 2009). I was proposing changing their way of moving, and therefore of thinking, through the performance of running. This move opened up a research setting with great potential. Rather than facing my participants to collect information, I was running with them. By moving side-byside in the same direction, we overcame the static face-toface confrontation of bodies so characteristic of the common interview. Learning together how to 'run the wall' has been an exciting process of discovery and knowledge. Most of our discussions happened during our runs close to the prison walls. Many of the rigidities of communicating with each other disappeared while moving. Intimate confessions and personal life stories were revealed in a general atmosphere of relaxation and openness within the group. Running provided unique sensations to the prisoners from the beginning.

After the first run I went to have a shower, opened the door of the dressing room and felt on my face the fresh air of the door opening. I felt so well [...] and said: 'this is exactly the best of existence'. And cried. Really cried, and I am not 
one of those with easy tears (prisoner's words).

The experience of a first run leaves an impression in the body that is difficult to explain. It connects directly with the feeling of being alive: being shot out to into a sense of presence. The sensation of increased energy is very strong. Suddenly you wake up to a condition of lucidity that you don't ever want to forget or lose. Everyday life appears sleepy and apathetic. Running provides a new kind of presence. The discovery of this dimension is often contrasted sharply with the strictly controlled lives of prisoners: 'how can I feel so well while I am in prison?'. The contrast between the visceral feeling of being present and the many forms of identification and pressure imposed by the prison was striking. Nevertheless this paradox seemed not to create problems, but on the contrary facilitated a release of accumulated tensions and contributed to a process of self-awareness.

There is a crucial difference between identity and presence: the former is socially constructed through the interplay (games) of multiple forms of power, defined by Foucault as 'technologies of the Self' (1998); the latter emerges in the limit-experience ${ }^{5}$ and in this particular project through the practice of marathon running as a feeling of 'being alive' (Ingold, 2011). Resistance was possible through the perception of this new embodied pulse of life, a barycentre in movement that everyone experienced through running. In the performance of running, the identity of the subject tends to blur and expand. The sensation is that of an evaporation of the distinction between yourself and others. Running joins us together in a "pre-linguistic fashion, beyond the sensation of separated individualities opening to a sensation of presence within a broadened dimension of anonymity' (Maccagno, 2015, p.68).

During the project, each runner had his own plan to follow. 
Being a marathon runner is a vocation, transforming very rigid timetables into life's rhythm. It means choosing a discipline from the inside as a healing game to develop resilience. An increased sense of self appeared within the group. This feeling was connected to the practice of running itself. The participation in our group meeting became more and more frequent and focused. All the participants ran alone during the week and started to follow their individual programmes with greater commitment than at the beginning. It was possible to register a gradual and incremental process of learning along with an increased feeling of pleasure. The cumulative and repetitive aspect of running started to transform the lives of the prisoners. They were interested in maintaining the regularity of their runs which provided them with a time and space suspended from the normal routine of the prison. Running produced a liminal dimension for self-creation. The discipline of training entered their lives and they felt an attachment towards it. They felt that they had the right to that feeling and had to protect it, resisting.

Even if it is raining we want to go running. No matter if the guards complain and try to convince us not to go today. It is our day of training and it doesn't matter if we get wet (prisoner's words).

A rich vein of work (Dirsuweit, 1999; Baer, 2005; Sibley \& van Hoven, 2009) has emerged around the nature and experience of carceral spaces, in which theorisations of incarceration underpinned by Foucault are contested. According to these studies, rather than being 'docile', prisoners express resistance to omni-disciplinary control through the reclaiming of prison space. Defending a space to run is in itself a resistant action. For each prisoner runner, as the participant implies above, 'running forever' became a movement of resistance to defend a space of neverending liminality. 


\section{The wall of the prison}

\section{The lost fathers}

One of the most important projects of Bambinisenzasbarre is The Yellow Space, a reception centre between the inside and outside of the prison, where children meet their parents. In continuity with that project, which confirms the well-studied porosity of the prison wall (Moran, 2013), Go Daddy! built a setting between inside and outside, where parenting could be overtly performed in this constructed environment. The marathon offered a very powerful ritual where fatherhood could be expressed: it is a common practice between marathon runners to dedicate the effort to their children and raise them in the air when they are crossing the finish line. That gesture is recognised as Ettore's gesture or the archaic gesture of the father (Zoja, 2000). In our Thursday training seminars, I gave prisoners suggestions of this kind through videos and short communications which raised many interesting discussions. During the preparation for the marathon, many races of different distances were organised inside the prison where families of the prisoners participated and fathers and children ran together, creating new ways for them to interact with each other that could transcend the dynamics of prison and its constraining effect on family relationships.

The marathon is in itself a huge challenge for anyone and immediately inspired in many of the prisoners a dream of redemption and the possibility of a more dignified interaction with their children than typically afforded by the prison. Being inside a prison often means to be deprived of your sense of self, hence the importance of proposing marathon running as an opportunity to increase one's own self-estimation and to engage with children in a dignified manner. Prisoners were invited to write letters to their children communicating their intention to participate in a marathon as an occasion to start a relationship on a different level. As a strategy for absent fathers to promote 
meaningful father-child interaction, they (father and child) were asked to prepare t-shirts for the race. They worked together in this preparation: on the front, the child was asked to make a drawing for his/her father and on the back the father was asked to write a message to dedicate to their child. The slogan on which we all agreed was: When everything crumbles, you can keep standing and running! The dream of the marathon, embedded in these fathers' words, is a message of resilience.

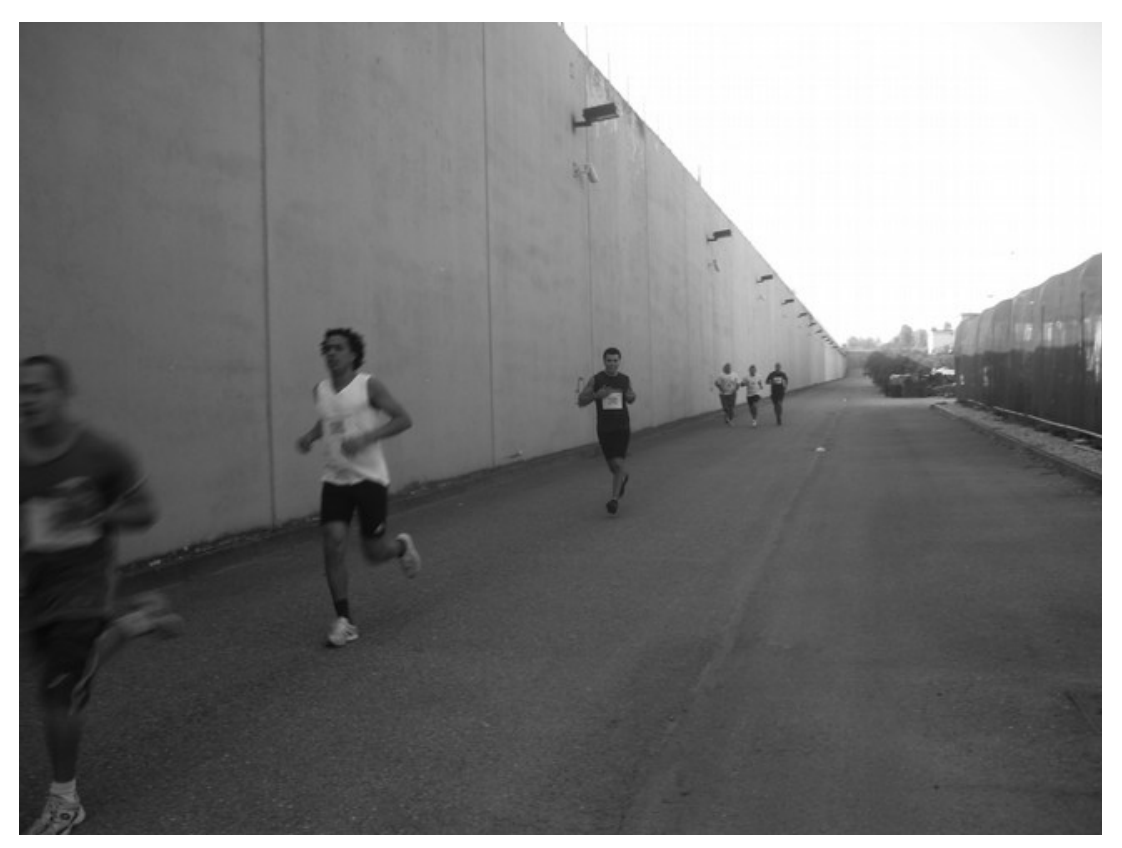

On 6 April, we realised that dream of participating in the Milan Relay Marathon with a team of 'lost fathers'. This name was decided upon by the group of prisoners, inspired by Peter Pan. Preparation for the marathon was a creative time where prisoners had the opportunity to reinvent their identity. We wrote together a tale to dedicate to the children where prisoners played the role of the 'lost boys'. They became the 'lost fathers' living in a Neverland who decided to run a marathon for their children. Under this label we included fathers not necessarily in prison who nonetheless considered themselves as part of the team, helping us to bring the marathon runners to the finish line in Milan city 
centre (not all the prisoners had permission for day release on the day of the marathon). Fatherhood provided a crossing of dimensions, between inside and outside: 20 runners, comprising those serving time in prison and runner-fathers from the outside (the 'free'), ran the race together. Our marathon started inside the prison, where ten fathers (seven prisoners and three 'free') ran their six miles. Immediately afterwards, the marathon continued outside where other participants (seven 'free' and three prisoners who obtained permission) ran to connect the inside of the prison with the outside of the official Milan marathon route. Here the team of fathers crossed the finish line at Sforza Castle where they concluded their race by raising their children in the air. Everyone, fathers inside and outside alike, received a medal for participation and a picture with their child, in a process that de-stigmatised and conferred dignity. At the Milan Marathon Awards 2014, Go Daddy! received the prize for the best project connected to running. The Go Daddy! team went beyond the wall with a symbolic bridge between inside and outside, binding the 'lost fathers' together into one team.

\section{Volunteer-prisoners or prisoner-volunteers?}

This is the 'land of freedom'. Yet I lost my desire to run. I want back my hour of air to go out running, to get clean, to feel the wind through my hair (prisoner's words).

Bringing the practice of the marathon into the 'land of freedom' of the Bollate prison was an important focus for research. This prison is unique in Italy: it explicitly positions itself as a benevolent moral institution and appears as a welfarist unit par excellence. Inside, punishment and rehabilitation co-exist somewhat uneasily, with neoliberal penality standing in tension with the government of love, 
friendship, and tolerance ${ }^{6}$. From this perspective, Go Daddy! has provided an opportunity to study the neoliberal penal state (Muehlebach, 2012), of which Italy represents an interesting site of analysis'. As Wacquant states 'the study of the prison becomes a window into the deepest contradictions and the darkest secrets of our age' (2002, p.389). The project situated itself coherently within the institution and its moral philosophy. Exploiting the rhetoric of sacrifice and strain, a foundation of the marathon, it got inside in a harmless way, with recognisable features, within the walls of the prison, as a moral project ${ }^{8}$. In this paradigmatic context, the intention of the project has been to define a setting where the subjectivity of the inmates is placed within tensions between freedom, rehabilitation and punishment: a way to study moral authoritarianism in the field. The hypocrisy of a hidden power masked under the skin of an illusionary freedom is what characterised the normal life of the prisoners in their attempt to find ways of moral rehabilitation within the aggressive penal bureaucracy of the institution: prisoners are subject to a strict monitoring regime where inmates' capacity to engage in positive relations is scrutinised. Every prisoner has his/her own educator and a personal percorso trattamentale (path of rehabilitation) that is periodically checked and revised. Depending on their progress, he/she can receive permission to go out, to work out, to get out earlier. What the Bollate prison is metaphorically saying to the prisoners is that the walls do not exist any more, because the possibility of getting out is in their hands: they are asked to become 'volunteers' in their own rehabilitation. It is common practice to ask prisoners to participate in menial jobs like cleaning carceral spaces such as common rooms and corridors. Many accept these in order to show their positive attitude and maintain good relationships with the guards and their educators. Others simply refuse to be volunteers and prefer to 'walk the corridors' (prisoner's words). Prisoners are crushed in such tensions and many of them want to change prison and leave the 'land of freedom'. 
My desire to "know from the inside" drove me to be a volunteer. This provided me with the recognisable identity in the eyes of the institution required to run the project. Only thanks to Bamibinsenzasbarre did I have the opportunity to enter the prison. The idea of the project was in my mind for many years but I needed a precise role to get inside: the institution demands an identity that fits with their programmes and regulations. According to Muehlebach (2011; 2012), in Italy, volunteering is part of a process of neoliberal governance which considers a progressive empowerment of the private sector and of the citizens' individuality. A volunteer is one who accepts not to be paid in order to be a citizen. He wants to work so as not to be excluded. I personally suffered many tensions because of the contradictory feelings experienced during the project. I was disappointed by the limited financial resources, and at the same time happy for the progressive success of our work.

The prisoner and the volunteer both participate in these moral activities in order to find their place within frames of identification in a neoliberal state.

How can I be a father in a world like this? They call it the 'land of freedom' and they open a door... so you start running to go through it but then you hit against something and suddenly realise that it is closed with glass. It is better that the wall is a wall. Yes, I prefer to be a slave and know it. Know when I have my hour of air (prisoner's words).

Bringing the marathon within the walls was an action to emphasise the existence of the physical wall: to make it obvious, to underline it, to run along it. Like a piece of land art revealing the landscape as if seen for the first time, in the same way the marathon highlights the wall, making it visible, finally cleaning it from false hypocrisies of freedom. 
The marathon is the awareness that the wall is there, that you cannot avoid it. My identity in the eye of prisoners, as I introduced myself to them for the very first time, was of a marathon runner-I was their trainer. I was not there to study them-they were not my research objects to collect data from. My action was closer to one of an artist who engages in 'experiments', in the sense not of testing a hypothesis but of opening an exploratory path of inquiry in human life. The decision of reflecting on the experience as a social scientist came afterwards, from the awareness of discovered potentiality under which Go Daddy! appeared as a pilot project for wider research. During the one and a half years spent together, many things happened: the people involved came out from their separated individualities, started to talk to each other, gained a mutual understanding of their common situation. The secrets between prisoners, where no one knows about you and the crime you committed, started to unravel. Thanks to a neutral and liminal identity as marathon runners, all of us started to recognise a possibility of communication, creating awareness and releasing the sense of blame that burdened everyone. Many of them gave up hope for early release and stopped engaging with the proposed new rehabilitative programmes in order to have just their 'hour of air' (prisoner's words). The desire to participate in the marathon comes from within and coordinated all of us. In the end I realised something that in the beginning I could not even confess to myself: I was not there for them, I was there for myself. And so together we ran walls, the wall of the marathon runner, the walls of the prison, the invisible walls that man is continuously building to secure himself... Running is 'dwelling poetically'.

\section{Performance on the edge of life}

In June 2014, we had our last meetings and runs. I knew I could not continue with the project at that moment but I felt 
it was not a definitive separation. Even if good educational practice normally advises finding a proper way to end the path together, I did not feel so pressed by the necessity of saying goodbye. My surprise was discovering that the prisoners felt the same. When asked about what they were going to do now, many of them answered: 'After this I will continue to participate to marathons and most of all keep on running' (prisoner's words). The systematic and repetitive practice of running in the long term can transform life and become a philosophical practice of care of the self: '[b]eing a marathon runner is a sort of transparency appl[ied] to everyday life. [...] an escape from the world in the world' (Maccagno, 2015, p.67). From this point of view, the project did not finish; it just opened to the prisoners a dimension of neverending liminality as a result of the practice of marathon running.

This argument destabilises the notion that liminality represents a space of linear transformation from one state to another as it has been introduced first to anthropology by van Gennep (2010) with the triphasic structure of the rite (separation-margin-aggregation) and developed by Turner (1969) with the idea of liminality as a suspended 'anti-structure'. This linear progression through the preliminal, liminal and post-liminal stages has been contested by different scholars (Phillips, 1990; Willett and Deegan, 2001; Moran, 2013) who note a state of permanent liminality where individuals become identified with a state of 'betweenness'. Within this body of research, the project presented here suggests that marathon running in prison operates as a 'repetitive threshold-crossing, where transformation is temporary and transient, but also cumulative' (Moran, 2013, p.349). Prisoners as runners entered repetitively the liminal dimension of 'running forever', affecting and transforming their lives.

The notion of limit emerging from this research highlights 
that in the lived and phenomenological experience of the limit, borders between inside and outside, between stage and real life, may not exist. The performance of the limit does not shift between what Turner called 'states' (1967, p.93). On the contrary, it is a continuous becoming which 'has neither beginning nor end' (Deleuze and Guattari, 2004, p.323). Ingold expands on this, saying that a line of becoming always prises an opening, defining a landscape where 'there are no insides and outsides, no enclosures or disclosures, only openings and ways through' (2011, pp.8384). In this context the role of the performance is one of an awakening to an energetic sense of presence.

'For me performance is the tool that I choose to make myself present' (Abramović quoted in Akers, 2012, p.19). Marina Abramović, a pioneer of performance art, affirms that performance is deeply founded on presence. In her exhibition at MoMA, The artist is present (2010), she performed in the atrium of the museum every day for three months. Visitors were encouraged to sit silently across from the artist for a duration of their choosing, becoming participants in the artwork. Talking about this experience, Abramovic said that this has been her work with 'the greatest potential in transformation [...] a sort of extension of vital energy' (ibid., p.42).

In every moment people are passing to get to the cafeteria, to the cinema, in the gallery, to the first and second floor: it is a continuous flow of people. I thought that if I would have created a small zone in the middle of that movement, as the centre of a tornado that is quiet, I would have created a situation between me and the people without conditions of time (ibid., p.46).

There is a similar creative approach to stage and setting in both the Go Daddy! project and the Abramovic exhibition: bringing the fragile and liberating movement of marathon 
running to the heart of a tornado of technologies of identification (Foucault, 1998) resounds with Abramović's decision to position her silent performance at the centre of oppressively frantic human movement. They both open a 'quiet' space for a limit-experience of de-subjectification (Foucault, 1994, p.43), 'without conditions of time' (Abramović, quoted in Akers, 2012, p.46). The striking contrast of energies creates the possibility of a performance on the edge of life, where presence is a possibility of freedom.

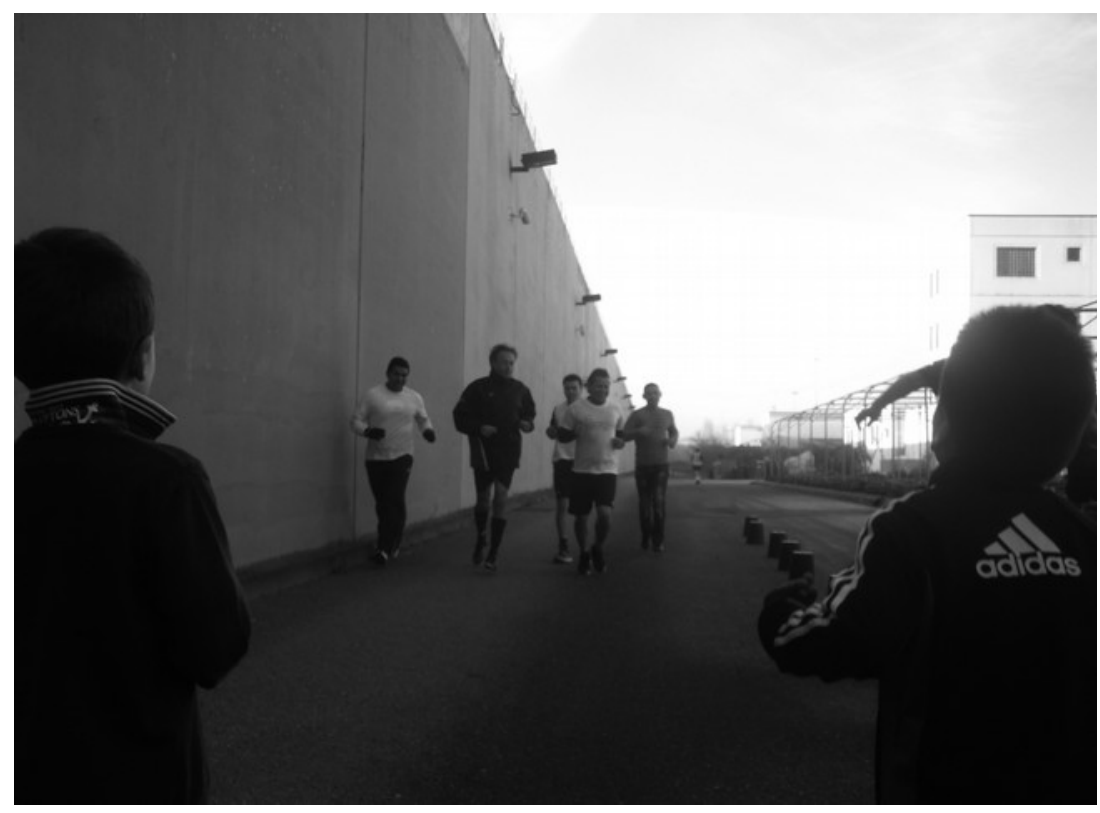

\section{Conclusions}

Marathon running acted as a catalyst of resistance and a cathartic space for limit-experience for the prisoners participating in the Go Daddy! project. 'Running forever' was a message to keep in mind while running but at the same time it was a very powerful seed planted in each participant's own life. Learning to run the 'wall of the marathon runner' had become a practice of freedom. The effect of such practice, according to Holmes et al., 'is not 
predictable, not scientifically measurable' (2006, p.328). Indeed, unpredictability is a characteristic of liminal carceral spaces, as highlighted by Moran (2013), and of liminality in general. The Go Daddy! project challenges more conventional methods of research in trying to deal with that characteristic. Moreover, it offers a new conceptual idea for academic inquiry: an art performance as a learning process to open an exploratory path of inquiry into human life.

Go Daddy! resulted in a creative practice of the limit, where I was able to observe and participate in a process where boundaries between inside and outside were continuously crossed and put into question (run outside the normal spaces of the prison, organise a race inside, invite parents from outside to come inside the prison for the race, participate in a real marathon outside the prison). It was a way of deconstructing the architecture of the prison, bringing the inside and the outside together on a totally indistinct threshold.

Go Daddy! was conceived as a pilot project to challenge the institution of the prison: moving away from punishment, towards rehabilitation. It is now going to be developed into a wider research initiative around performance studies and prison identities in other European countries involving academic institutions and associations (Children of Prisoners Europe ${ }^{10}$, Bambinisenzasbarre). A further step is to propose alternative paths of rehabilitation such as, for example, pilgrimage instead of detention: a marathon can become a real pilgrimage into a landscape and offer a possibility of rehabilitation in confrontation with the wilderness. The project will contribute to wider developments of carceral systems and to positive social change. This way of undertaking anthropology constitutes an investigation into the anthropology of the limit and is part of my larger programme of research that investigates 
new possibilities of freedom in a neoliberal era. In seeking ways to answer to the world, the practices of the limit give expression to an anthropology through movement of hope, care, and inspiration.

\section{Notes}

1.See: $\underline{w w w . b a m b i n i s e n z a s b a r r e . o r g}$.

2.The Feldenkrais method is a somatic educational method based on movement.

3.The limit-experience does not have to be confused with research of the extreme to test one's physical possibilities, as many sports activities seem to show nowadays. Neither is it a temporary phase in a rite of passage (van Gennep, 2010) as commonly understood by traditional anthropology (discussed later in the article). The limitexperience, on the contrary, is never excessive, certainly challenging but possible. It is not an unconscious desire for death, but hope of an awakening to a more intense sense of life.

4.As Merleau-Ponty states, 'a bodily movement carries its own immanent intentionality’ (1962, pp.110-111).

5.Foucault asserts that subjectivity is fluid and always seeking lines of escape from governing agencies (1998). The Self responds to these normalising processes not by trying to free itself from this regulation, but rather by inventing alternative practices, which Foucault identified as 'pratiques de liberté' (practices of freedom) (Holmes et al., 2006).

6.Upon entry, prisoners sign a contract binding them to an ethic of non-violence and non-discrimination against the prison's large (35\%) immigrant population and sex-offender population. Such contractual binding to an ethic of tolerance also includes cultivating a spirit of comanagement, participation, and peer-counselling.

7.In 2010, the Italian government declared a state of emergency in the country's prisons and launched a plan to tackle its catastrophic overcrowding and high suicide rates. The plan entailed the expansion of prisons and the hiring of thousands of new guards and must be situated within a global explosion in the growth of prisons since the 
'epochal shift from the social to the penal treatment' of social ills (Wacquant, 2008, p.51). As is the case elsewhere, Italy has seen almost total abandonment of the ideal of rehabilitation, with prisons increasingly serving to warehouse inmates. Italy is an interesting site of analysis because of its long history of authoritarianism due to the after-effects of Fascism as well as the culture of Catholicism that both reinforces and mitigates against this authoritarianism.

8.Due to the presence of a strong Catholic culture, morality is a rhetoric on which a practice of rehabilitation is based that conceptualises wrongdoing through cycles of punishment and forgiveness, sin and salvation.

9.Knowing from the inside is the title of a project of research led by Professor Tim Ingold at the University of Aberdeen (http://www.abdn.ac.uk/research/kfi/). Its fundamental premise is that knowledge grows from our practical and observational engagement with beings and things around us.

10.See: http://childrenofprisoners.eu/.

11.The video Go Daddy! The dream of the marathon, edited by the author in May 2014, is available at: https://youtu.be/wdOIXV4SZ14. Ethical approval has been received.

\section{Acknowledgements}

This project is dedicated to all 'lost fathers' prisoners of a world of walls. To all friends of solitude.

I would like to thank Lia Sacerdote, President of Bambinisenzasbarre, who welcomed the idea of the project helping me to develop it. A particular thank you to Andrea Muehlebach (University of Toronto) with whom I had many interesting discussions about neoliberalism which provided a fundamental background to the project. I would also like to thank the three anonymous reviewers whose insightful comments have helped to significantly sharpen the theoretical underpinnings and narrative of this article. 
Scottish Journal of Performance

Volume 2, Issue 2

\section{References}

Akers, M., 2012. Marina Abramović: the artist is present. Milan: Feltrinelli.

Baer, L., 2005. Visual imprints on the prison landscape: a study on the decorations in prison cells. Tijdschrift voor Economische en Sociale Geografie, 96(2), pp.209-217. http://dx.doi.org/10.1111/j.14679663.2005.00451.x.

Dave, N.N., 2012. Queer activism in India: a story in the anthropology of ethics. Durham, NC: Duke University Press.

Deleuze, G. and Guattari, F.,2004. A thousand plateaus: capitalism and schizophrenia. London: Continuum.

De Martino, E., 1997. Il mondo magico. Prolegomeni a una storia del magismo. Turin: Bollati Boringhieri.

Dirsuweit, T., 1999. Carceral spaces in South Africa: a case study of institutional power, sexuality and transgression in a women's prison. Geoforum, 30(1), pp.71-83. http://dx.doi.org/10.1016/s0016$\underline{7185(98) 00030-x}$

Foucault, M., 1994. Dits et écrits. Vol. 4. Paris: Gallimard.

Foucault, M., 1995. Madness: the absence of work. Trans. P. Stastny and D. Şengel. Critical Inquiry, 21(2), pp.290-298.

http://dx.doi.org/10.1086/448753.

Foucault, M. 1998. Technologies of the self: a seminar with Michel Foucault. Cambridge, MA: University of Massachusetts Press.

Holmes, D., O'Byrne, P. and Gastaldo, D., 2006. Raw sex as limit experience: a Foucauldian analysis of unsafe anal sex between men, Social Theory \& Health, 4(4), pp. 319-333.

http://dx.doi.org/10.1057/palgrave.sth.8700077.

Ingold, T., 2011. Being alive: essays on movement, knowledge and description. London: Routledge.

Ingold T. and Vergunst J. L., 2008. Ways of walking: ethnography and practice on foot. Aldershot: Ashgate. 
Ingold, T., 2000. The perception of the environment: essays in livelihood, dwelling and skill. London: Routledge.

http://dx.doi.org/10.4324/9780203466025.

Jay, M.,1995. The limits of limit-experience: Bataille and Foucault. Constellations, 2(2), pp.155-174.

Lyng, S., 2004. Edgework: the sociology of risk-taking. London: Routledge.

Maccagno, P., 2015. Lungo lento. Maratona e pratica del limite. Macerata: Quodlibet.

Merleau-Ponty, M., 1962. Phenomenology of perception. Trans. C. Smith. London: Routledge \& Kegan Paul.

Meschiari, M., 2010. Terra Sapiens. Antropologie del paesaggio. Palermo: Sellerio.

Moran, D., 2013. Between outside and inside? Prison visiting rooms as liminal carceral spaces. Geo Journal, 78(2), pp.339-351.

http://dx.doi.org/10.1007/s10708-011-9442-6.

Muehlebach, A., 2012. The moral neoliberal, welfare and citizenship in Italy. Chicago, IL: University of Chicago Press.

http://dx.doi.org/10.7208/chicago/9780226545417.003.0002.

Muehlebach, A., 2011. On affective labor in post-Fordist Italy. Cultural Anthropology, 26(1), pp.59-82. http://dx.doi.org/10.1111/j.15481360.2010.01080.x.

Phillips, M. J., 1990. Damaged goods: oral narratives of the experience of disability. Social Science and Medicine, 30(8), pp.849-857. http://dx.doi.org/10.1016/0277-9536(90)90212-b.

Oksala, J., 2004. Anarchic bodies: Foucault and the feminist question of experience. Hypatia, 19(4), pp.99-121.

http://dx.doi.org/10.1111/j.1527-2001.2004.tb00150.x.

Sheets-Johnstone, M., 2009. The corporeal turn: an interdisciplinary reader. Exeter: Imprint Academic.

Sibley, D. and van Hoven, B., 2009. The contamination of personal space: boundary construction in a prison environment. Area, 41(2), pp.198-206. http://dx.doi.org/10.1111/j.1475-4762.2008.00855.x. 
Sims, R., 2001. Can my daddy hug me? Deciding whether visiting Dad in a prison facility is in the best interest of the child. Brookings Law Review, 66, pp. 933-970.

Skorpen, A., Anderssen, N., Oeye, C., and Bjelland, A. K., 2008. The smoking-room as psychiatric patients' sanctuary: a place for resistance. Journal of Psychiatric and Mental Health Nursing, 15(9), pp. 728-736. http://dx.doi.org/10.1111/j.1365-2850.2008.01298.x.

Stevinson, C. D. and Biddle, S. J., 1998. Cognitive orientations in marathon running and 'hitting the wall'. British Journal of Sports Medicine, 32(3), pp.229-234. http://dx.doi.org/10.1136/bjsm.32.3.229.

Tobias, S., 2005. Foucault on freedom and capabilities. Theory, Culture \& Society, 22(4), pp.65-85. http://dx.doi.org/10.1177/0263276405053721.

Turner, V., 1987. The anthropology of performance. New York, NY: PAJ Publications.

Turner, V., 1969. The ritual process: structure and anti-structure. Chicago, IL: Aldine Publishing Company.

Turner, V., 1967. The forest of symbols: aspects of Ndembu ritual. Ithaca, NY: Cornell University Press.

Van Gennep, A., 2010. The rites of passage. Abingdon: Routledge. http://dx.doi.org/10.7208/chicago/9780226027180.001.0001.

Varela, F. J., 1996. Neurophenomenology: a methodological remedy for the hard problem. Journal of Consciousness Studies, 3(4), pp.330-349.

Varela, F., and Shear, J., 1999. First-person methodologies: what, why, how? Journal of Consciousness Studies, 6(2-3), pp.1-14.

Wacquant, L., 2011. The wedding of workfare and prisonfare revisited. Social Justice, 38(1-2), pp.1-16. http://dx.doi.org/10.1080/10875549.2012.695540.

Wacquant, L., 2010. Crafting the neoliberal state: workfare, prisonfare, and social insecurity. Sociological Forum, 25(2), pp.197-220. http://dx.doi.org/10.1111/j.1573-7861.2010.01173.x.

Wacquant, L., 2008. Urban outcasts: a comparative sociology of advanced marginality. Cambridge: Polity Press. 
Wacquant, L., 2002. The curious eclipse of prison ethnography in the age of mass incarceration. Ethnography, 3(4), pp.371-397.

http://dx.doi.org/10.1177/1466138102003004012.

Wacquant, L., 2000. The new 'peculiar institution': on the prison as surrogate ghetto. Theoretical Criminology, 4(3), pp.377-389.

http://dx.doi.org/10.1177/1362480600004003007.

Willett, J., and Deegan, M. J., 2001. Liminality and disability: rites of passage and community in hypermodern society. Disability Studies Quarterly, 21(3), pp.137-152.

Zoja, L., 2000. Il gesto di Ettore. Preistoria, storia, attualità e scomparsa del padre. Turin: Bollati Boringhieri.

\section{About the author}

PAOLO MACCAGNO is an anthropologist, Feldenkrais practitioner, architect and marathoner. He has spent 15 years as a landscapearchitect, and is engaged in ongoing life-research on the notion of limit focusing on movement, body and touch. He is the author of practices of anthropology of the landscape and art-performances meant to be practices of the limit. He is currently studying for a PhD at the University of Aberdeen under the supervision of Professor Tim Ingold and Dr Jo Vergunst. 